\title{
КАТАЛОГ МАНАСТИРА У НАРОДНИМ УМОТВОРИНАМА СА КОСОВА И МЕТОХИЈЕ**
}

У раду ћемо се бавити каталогом манастира у народним умотворинама са Косова и Метохије, које налазимо у лирским, епским и приповедним песмама, као и у предањима. Пратићемо транспозицију сакралне грађевине у усмени текст у етнопсихолошкој заједници која је била на извору духовног и материјалног наслеђа српског народа.

Показаћемо шта је народном певачу било занимљиво у односу на манастире чији су ктитори били из реда владара и који су у времену под Турцима били духовно уточиште српског народа. Манастир Грачаница, Дечани, Девич и други чине каталог који је народни певач стварао и у песми и у прозним облицима, певајући и приповедајући о њиховој градњи, али и о уточишту за невољне. Њима је дато посебно место у усменом наслеђу, али је за народног певача било важно да покаже не само њихову духовну функцију већ и важну улогу опстанка под Турцима. Народни певач је приповедао о градњи Дечана и Грачанице и стварао каталог манастира ослањајући се на архаично наслеђе у којем је градња сакралне грађевине захтевала одређену жртву. У раду ћемо показати да у усменом наслеђу каталог манастира можемо пратити кроз призму старог и млађег слоја певања, што је један од важних циљева овог истраживања.

Кључне речи: Косово и Метохија, манастири, цркве, задужбине, Грачаница, Дечани, Света Петка, Света Недеља.

Када говоримо о каталогу манастира у усменом наслеђу Косова и Метохије, фокусираћемо се на неколико начина сагледавања њихове функције имајући у виду територију која је била значајна за религиозно поимање света. Како је аутокефалност српске цркве везана за простор Старе Србије, намеће се питање на који начин је народ гледао на све оно што се у реалности дешавало, какав је био његов однос према Немањићима и према ономе што су они градили и како је народни певач транспоновао сакралне грађевине у усмено казивање.

*valentine.pitulic@pr.ac.rs

** Рад је рађен у оквиру пројекта Српско усмено стваралаштво у интеркултурном коду (бр. 178011), који финансира Министарство просвете, науке и тохнолошког развоја Србије. 
Каталог манастира у колективном усменом наслеђу Срба са Косова и Метохије нешто је другачији од каталога у другим срединама. У њему ће се наћи углавном они манастири и цркве који су били у видокругу народног певача, а то су: Грачаница (Грачанка), Високи Дечани, у Пећи Свети Арсеније, Девич у Дреници, св. Арханели код Призрена, ирква Хилендарка, ирква Света Петка и Света Недељь, ирква Петровка, Света Софија, ирква св. Илије у Вучитрну, ирква Петровица, ирква Св. Јанићију, ирква Ружица, ирква Св. Богородице у Мушутишту, више Породимља светог Уроша, Раваница на води Ресави, више Митровице Сокољииа, у сред Призрен иркву свету Петку, бела ирква, ирква шарена.

Ако говоримо о црквама и манастирима, неизоставно морамо поменути и песме у којима се црква гради сама од себе. У митолошкој песми у којој вила зида град ни на небо ни на земљу присуствујемо градњи чудесног града који је за Миодрага Павловића имао значење „химне најстаријег типа” (Павловић 1993: 24-31). Градња небеског града представља неку врсту прапочетка свих будућих грађевина које ће доживети извесну трансформацију, односно лагно спуштање са небеског на земаљски план. Да је почетак градње небеског града била слика која ће кроз време са небеског да се спусти на земаљско, показују управо лирске песме са Косова и Метохије. У њима ће доћи до извесне супституције појединих симбола, а пре свега града који је замењен црквом, где долази до сакрализовања нехомогених простора (Елијаде 2003: 82-85). У лирској песми са Косова и Метохије, коју је забележио Дена Дебељковић, град на облаку замењен је црквом која се гради сама од себе, на једну грањку. Овај чудесан чин стварања, где вила полако уступа место необичној градњи цркве, која се гради сама од себе, има упориште у хришћанству, где је сам чин стварања света тајно дело Божијеㄹ. У песми долази до лагане трансформације митолошких слојева, па се у једном тренутку чини да народни певач, заправо, ствара представу накићеног дрвета, осе света, која стреми ка небу и повезује доње и горње делове света (Ајдачић 1996: 69). Необична је и слика цркве која се, гради сама од себе, ни на гору ни на воду. Дрво, као паганско светилиште полако се замењује црквом, што потврђује тврђење Веселина Чајкановића да је дрво („света дрвета”) ништа друго него „најпримитивнији храмови” (Чајкановић 1994: 172).

Народни певач градњу цркве смешта у митолошке просторе градње небеског града. У митолошким песмама вила гради град ни на небу ни на земљи, али у песмама са Косова и Метохије долази до лагане христијанизације где се древна градитељица, вила, губи, а место града гради се црква, и то сама од себе:

Саздаде се бела црква

Ни на небо ни на земљу,

На сред небо под небеса.

(Бован 1, 1980: 175).

${ }^{1}$,Ja sam alfa i omega, početak i svršetak, govori Gospodin, koji jest i koji bješe, i koji će doći, svedržitelj" (Otkrovenje, 1, 8). 
Однос према Цркви најбоље се види у лирским народним песмама у којима је доминантан близак однос народа са сакралном грађевином. Занимљиво је да је на територији у којој је, по Јовану Цвијићу, доминантан рајински менталитет, са богатим византијским налеђем (Цвијић 1991: 325329) свакодневни живот био везан за Цркву. У средини где је концентрација цркава и манастира била велика она је била део свакодневног живота. То најбоље видимо у песми која се певала на Божић:

Мала мома цркву мела,

Цркву мела Богу се молила:

„Дај ми, боже, свекра попа,

А свекрву попадију,

Младо момче самоуче,

А девера калуђера,

А јетрву калуђерку".

Што молила, домолила.

(Бован 1, 1980: 60).

У молитви упућеној Богу, а која се догађа у цркви, она жели ђаче самоуче, што говори о јакој присутности учености у средини у којој се одвијао богат црквени живот који је подразумевао присуство књиге. Њена молитва усмерена је ка дому у који би желела да се уда, а у којем би била духовна лица (свекар поп, свекрва попадија, девер калуђер). У једној сватовској песми девојка се у цркви моли Богу да јој каже где јој је драги (У цркву сам била / бога сам молила (Бован 1, 1980: 146). Свакодневно сусретање са црквеним људима види се и у љубавним песмама где девојка каже да је била у митрополији да се жали на драгог који је вара:

Де си била, Недо, Недо Чанаклијо?

„Ја сам била, прото, у митрополију

Ђорђа да осидим што ме младу вара.

(Бован 2, 1980: 39).

Присуство цркава и манастира не налазимо само у верским песмама већ и у сватовским и љубавним, што говори о начину живота Косоваца, односно свакодневној комуникацији цркве, митрополије, порте и народа. У једној песми се пева:

Риска седи на тој доње порте, Трајче иде кроз трумпин сокака,

Па јој рече: „Христос се роди!”

Она њему: „Ваиста се роди!”

(Бован 2, 1980: 180).

Занимљиво је да се црква појављује и у додолским песмама, које су дошле из времена пре појаве хришћанства, што говори о замени старих симбола новим, хришћанским. У овим песмама се најбоље види колико је народ 
ишао у цркву и имао један посебан однос према свештенству, литургији, али и свим пословима у вези са црквом у којима су учествовали. Велика упућеност у црквени живот види се и у додолској песми у којој додолица сиротица моли Бога да јој пошаље ситну росу, да у село падне киша, да роди пшеница, да месимо поскурице / да носимо беле иркве / беле иркве св. Пречисте (Дебељковић 1984: 22). У обредним песмама се на известан начин врши христијанизација у којој црква има централно место.

У једној крстоношкој песми, која је христијанизована додолска, молитва је, уместо божанству кише, Додоли, упућена Богу, са истом молитвом која се упућује Додолици, да пошаље берићет. На крају песме у молитви се жели да киша пороси све, а наше поље понајбоље / света Петка и Недеља / бела ирква св. Пречиста (Дебељковић 1984: 23). Песму је забележио Дена Дебељковић, и у њој су маркиране три цркве: Света Петка, Света Недеља и Св. Пречиста. Црква Св. Петка често се помиње у песмама са Косова и Метохије, а у једној песми појављује се синтагма стара света Петка која се назире са неког горњег простора:

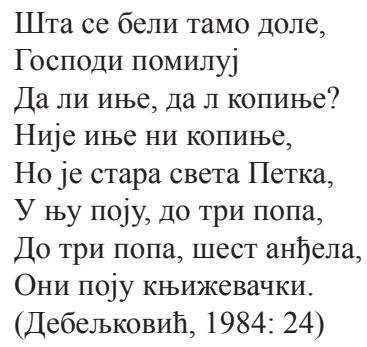

За разумевање односа народа према цркви значајни су записи Ивана Степановича Јастребова, посебно оних који се односе на обичаје приликом прославе крсног имена. Симболичну евхаристију видимо у обичају да домаћин ломи славски колач у кући, полива га вином, а сваки члан породице узима хлеб и пије вино, као симболичну замену за евхаристију коју обавља свештеник.

Утицај црквеног богослужења најбоље се види у запису Ивана Степановича Јастребова, који пише да се на слави изговарао исти текст који се чита у цркви на богослужењу (Во славу иже во Троицъ славимому Господу Исусу Христу нашему Богу во премногія молби и мольни пресвятъй и пречистьй и преблагословенъй славнъй Владичищи нашея Богородици и приснодъвьь Маріи...) (Јастребов 1886: 14).

Неименоване цркве налазимо у приповедним песмама. Она је и овде сакрални простор у којем огрешење од стране човека бива кажњено. У њима се кажњава почињени грех, као у песми „Јанко гради на ливади грађу” у којој је Јанко у Витош планини па он нађе до две беле иркве / па и сруши од вр до темеља / у темељу два златна ковчега / и у юима две лепе девојке / то не биле две лепе девојке / већ то биле две лепе сестрице / света Петка и света Недеља (Бован 3, 1980: 64). Овде налазимо устаљену формулу кажњавања преступника који због почињеног греха не може да испусти душу (Милоше- 
вић-Ђорђевић 1971: 235-238) (кроз кости му проникнула трава) (Бован 3, 1980: 64). У свим фолклорном жанровима поступак кажњавања грехова је исти, а налазимо га и у приповедним песмама са Косова и Метохије.

Посебан круг песама су оне у којима је приказана борба за манастире који су угрожени од Турака. Појављују се и анахронизми, где цркве брани Свети Сава, уз помоћ ђачета самоука. У свести колектива Свети Сава ${ }^{2}$ је имао значајно место. Одлазак у цркву, близина Пећке патријаршије, фреске са ликом Светог Саве, као и неговање његовог култа рефлектовало се у додељивању Светом Сави улоге бранитеља од Турака. Анахронизми, који су честа појава у усменом наслеђу, и овде ће бити у функцији прављења каталога манастира из различитих времена, али се задужбине које су градили Немањићи приписују Светом Сави. Каталог манастира дат је тако што је одређена и њихова позиција, поред воде или у градовима. У песми „Сава калуђер и цар Сулејман” каталог изгледа овако:

Међу Пећи, међу Ђаковицом, Градио сам Високе Дечане, И у Пећи Свети Арсеније, И у Девич Свети Јанићије, У сред Призрен цркву Свету Петку, И уз реку светог Аранђела, Градећ цркву Хилендерку, У Косову цркву Грачаницу (Бован 3, 1980: 67).

Тражење Пећке патријаршије у каталогу манастира је узалудно, а мало вероватно да је народни певач заобишао овако важну задужбину. И није. У каталогу се Светом Сави приписује грађење (И у Пећи Свети Арсеније) најстарије цркве у Пећкој патријаршији, коју народ назива Свети Арсеније 3 , што иде у прилог томе да је у колективној свести народа живело памћење о почетку градње овог манастира.

У приповедним песмама углавном је опевана одбрана цркава од Турака, где молитва и литургија помажу да црква буде одбрањена, као у песми „Сава калуђер и цар Сулејман” (Бован 3, 1980: 66).

Народни певач је издвојио и манастир Грачаницу, задужбину краља Милутина, која је у лаганој христијанизацији заменила јелу, као сакрализовани

2 „Будући одличан познавалац психологије масе, Сава Немањић је за живота учинио све што је било у његовој моћи да у народној свести појам српске државе и српске државности представи као нераскидиву спрегу државе и цркве, јединство световне и духовне власти, земаљског и небеског царства. Свестан да су темељи битни основ сваке солидне грађевине, Сава је настојао да у народну свест утисне као аксиомско спознање, како српска самостална средњовековна држава и српска самостална црква происходе из световнога деловања оца му Немање и духовног настојања и бриге њега самог” (Љубинковић 2010: 198).

3 „Најстарија црква, посвећена Св. Апостолима, касније Св. Спасу, саграђена је, највероватније, у другој четвртини 13. века, на месту некадашњег метоха манастира Жиче, првобитног архиепископског средишта Српске Цркве у средњем веку. Ктитор је био Архиепископ Арсеније I. Око 1250. године црква је први пут и живописана." - Задужбине Косова и Метохије, историјско, духовно и културно наслеђе српског народа; друго, допуњено издање, Призрен-Београд, 2016, стр. 31. 
простор древних Словена. На старо језгро митолошкох песама, где је дрво представљало осу света, јелу је заменила црква. У једној митолошкој песми дата је слика Грачанице, како народни певач каже Грачанка, која на чудесан начин замењује дрво:

\footnotetext{
Порасла јела до неба Савила гране до земље, На грању лишће зелено, На лишћу цвеће црвено, На цвеће челе попале. Што ми је јела висока, То ми је црква Грачанка; Што ми је лишће зелено, То су ми књиге црквене; Што ми је цвеће црвено, То ми је причес у цркви; Што су ми челе попале, То ми је народ у цркви (Бован 1, 1980: 174)
}

Народном певачу је било важно да се у једној песми, у саборном смислу, појаве црква Грачаница, црквене књиге, причест и народ, што представља пуноћу црквеног, односно евхаристијског живота. У песми из збирке Дене Дебељковића, са истим мотивом, Света Недеља лежи Светом Петру на крилу, а Свети Петар је буди и показује јелу, која негацијом постаје црква Грачанка (што су ми листи широки / то су ми књиге попове / што ми је цвеће црвено / то ми је причес у иркву / што су ми пчеле попале / то ми је народ пред иркву (Дебељковић 1984: 21).

Црква Грачаница показана је и из једне друге перспективе, можемо рећи причије. Она се налази доле, на земљи, али је народни певач сагледава са позиције неба, уводећи у песму горњи простор у којем Света Тројица спава Светом Петру на крилу, али је буди Света Недеља јер је изгрејало сунце. Света Недеља се пита шта се бели тамо, доле, да би добила одговор од Свете Тројице:

\footnotetext{
Није пена нит калпена?

Но се бели бела црква

Бела црква Грачаница,

У цркви су три анђела.

(Бован 1, 1980: 344).
}

Везу између облака и цркве налазимо и у предању о настанку манастира Грачанице, у којем краљ Милутин у сну, у облаку, види цркву са пет кубета и гради Грачаницу по моделу древног уређења света који долази одозго, јер симболика иркве, како би рекао Ерих Нојман, одговара првобитној митологији простора (Нојман 1994: 92).

Колико је Грачаница присутна у колективном памћењу Срба са Косова и Метохије показује и то што се она нашла и у епским народним 
песмама, и то у циклусу Краљевића Марка. Песма Марко избавља робље почиње устаљеном формулом сеја Марко с мајком да вечера да би у даљем делу песме Марко рекао мајци да је сутра Велигдан, да се спрема да иде у цркву Грачаницу и пита је да л да узнем сабљу димискињу / да л да узнем јаку топузину (Дебељковић, 1984: 263). Однос народа према цркви види се у одговору мајке Јевросиме која каже: Нећеш, синко цигер да разбиваш / но ти иди Богу са се молиш (Дебељковић, 1984: 263). Марко на путу ослобађа робље, али су песме са Косова и Метохије специфичне по томе што је црквени живот имао удела и у епској структури. Народном певачу је било важно да Свете тајне имају одређену функцију у епској песми. Наиме, у овом жанру Марко одводи робље у цркву Грачаницу па ги беше Марко причестија / причестија и себе исповедија (Дебељковић, 1984: 264). За народног певача било је важно да се јунак причешћује, што није одлика јунака са других српских простора. Тако ћемо са тачке гледишта колектива Марка често видети у ситуацији сад ће проћи Краљевићу Марко / он ће отић цркви Грачаници / те да тамо он узме причешће (Бован 5, 1980: 152).

Црква је често приказана као сакрално место које има моћ исцељења слепих и немих. У формули негације у песми Исцељеље слепих и немих народни певач именује иркву Петровку:

Фала богу фала јединоме

Што падоше три бела голуба,

Што падоше на цркву Петровку,

Нису били три бела голуба,

Но су били три божја анђела.

(Бован 3, 1980: 74)

У овој приповедној песми црква Петровка је место одакле крећу божји изасланици, анђели, Св. Петар, громовит Илија и Свети Никола да виде зашто Симон Ратар оре у Свету Недељу.

Задужбинарство, које је посебно обележило време владавине Немањића, транспоновано је у усмено казивање као важан моменат у животу владара, а оно је манифестовано преко каталога задужбина. Народни певач задужбинарство углавном везује за Немањиће.

Кад е било време Неманића,

Градили су многе задужбине,

Многе цркве па и манастире.

(Јастребов 1886: 239).

Колико је средина у којој је настајала песма утицала на оно о чему ће народни певач певати показује и песма из збирке Ивана Степановича Јастребова (Јастребов није давао наслове песмама) у којој је дат каталог манастира. Народни певач се фокусирао на манастир Светих Архангела, крај Призрена, задужбину цара Душана, који је срушен за врема Турака, а имао је велики значај у животу Срба у Старој Србији. О том велелепном манастиру који је, поред манастира Бањска, био један од најбогатије украшених нема података 
у песми. Народном певачу било је важно да остави податке о томе да су Немањићи градили манастир у Дрвена града, / у Дрвена светога Аранђела, али народном певачу је било важно и да проговори о судбини манастира (Свети Аранђел разрушен је сада) (Јастребов 1886: 239).

Ако бисмо у стиховима тражили и цркву Богородицу Љевишку у Призрену, задужбину краља Милутина, наше трагање било би узалудно. Она се у усменом казивању Срба не помиње под тим именом, али ћемо је наћи под именом Света Петка, која је претворена у џамију (народни певач каже потурчена сада) јер су је Косовци, посебно Призренци, тако називали. О томе податак оставља Иван Степанович Јастребов који каже: „Није тешко претпоставити да је петокуполна џамија под називом Џума Џами била градска саборна црква посвећена Успењу Богородице (у њеној основи је крст). Потурчивши је, Турци јој надену име Џума Џами - саборна џамија, а хришћани је, у преводу са турског, зову Света Петка (иума на српском значи петак - дан на који се Турци сабирају у џамију, те отуда Џума значи саборна)” (Јастребов 2, 2018: 105).

У свести народног певача сачувано је сећање на манастире који су порушени (као Свети Архангели), као и градњу манастира, али је оно по чему су се углавном памтили било то колико кубета имају и чије су задужбине (црква у Мушутишту једно кубе има, Грачаница пет кубета има, а црква више Породимља је црква светога Уроша (Јастребов 1886: 239). У каталогу манастира у народним умотворинама са Косова и Метохије, појављују се манастири које не налазимо у каталогу манастира на другим српским територијама, а то су мањи манастори и цркве који су срушени по доласку Турака и били су у видокругу колектива. Тако ће се у једној песми наћи и стихови да су Немањићи Градили (су) више Митровице / Митровице иркву Сокољииу, али ће се у каталогу наћи и Раваница на води Ресави, задужбина кнеза Лазара. С обзиром на то да је Дреница била територија којом је столовао Вук Бранковић и у којој је био „низ храмова, од којих је до данас у целости остао само манастир Девич” (Николић, 1997: 205), народном певачу је било важно да каже да су Немањићи градили Девич у Дренииу (Јастребов 1886: 240). У предању приповедач приповеда о цркви Светог Јанићија, која је настала на месту где је Јоаникије испустио душу после убиства цара Мурата. Занимљиво је да ова месна легенда врши супституцију актера савладавања хтонског (цар Мурат) тако што атрибуте јунака жртве (Милоша Обилића) преноси на Јоаникија, који се после иницијације у боју посвећује тако што издахне „негде између Митровице и Ђаковице”, сестра га сахрани и ту сагради цркву (Бован 4, 1980: 155).

У песмама са Косова и Метохије налазимо и мотив „последњих времена", који је инкорпориран у мотив о зидању манастира Дечани. На почетку песме дат је каталог мањих цркава, али је цела песма о зидању манастира Дечани. Сестрица Јелица говори цару Душану да не ради цркву од дуката да је не подниза ситнијем бисером и не покрива тешком оловином (Јастребов 1886: 240) јер ће доћи „последња времена” када ће Турци разорити цркву, што је „стилски и логички оправдан део прве Вукове варијанте „Зидање Ра- 
ванице” (Костић 1938: 205-216). Мотив о зидању манастира, уз стављање тежишта на последња времена, у овој варијанти фокусиран је на цара Душана, који је завршио градњу манастира Дечани коју је започео његов отац Стефан Дечански (Задужбине 2016: 107-138). Народни певач пева о последњим временима, с тим што се мењају актери који учествују у градњи манастира у односу на песму „Зидање Раванице” (Караџић 1969: 147). Цара Душана сестра моли да не зида раскошан манастир, што ће у Вуковој варијанти учинити кнегиња Милица или Милош Обилић.

Занимљива је градња Св. Илије у Вучитрну, из које се јасно види где су ишли средњовековни путеви. Тргује се са Сарајевом и одлази у куповину у Цариград. ${ }^{4}$ У овом предању налазимо детаље везане за одржавање грађевине (закопавање дуката на четири места да би се грађевина одржала, као и обичај да се принесе жртва у облику жртвовања шест овнова, у предању утицај турцизма „шест курбана”, где је забележено и сведочење да $и$ дан данас седи ражањ у ирквену избу. Народни приповедач оставља податке о градњи и завршетку цркве: „Црква се на само Воскрсеније почела. До Светога Саве је се црква венчала" (Бован 4, 1980: 131). Народни приповедач понекад помиње цркву као оријентир за друго казивање, као што је казивање о бору краља Милутина у Неродимљу (други бор је код неродимске иркве, с јужне стране (Бован 4, 1980: 132). Занимљиво је да у предању налазимо и цркву Петровицу, за коју жена прави просфору за литургију. У њој зимују хајдуци и немајући чиме да се огреју потпале све што је могло да изгори, да би се на крају због грехова исповедили.

У песмама са Косова и Метохије, поред локалних цркава и манастира који су били у видокругу казивача, налазимо и цркве које су са удаљених простора, као што је црква Ружичица, у коју одлази кнегиња Милица да јој протумаче сан де се небо на две предвоило де су звезде по земљи попале / и Даница как Стамбола бега (Бован 5, 1980: 66). Свештеник саветује Милицу да узме свећу од седамдесет ока / па да однесеш у иркву Ружичииу / то ће тебе у ништа да отидне (Бован 5, 1980: 67). Разумљиво је да су у колективном памћењу у овој етнопсихолошкој заједници фреквентније цркве које су биле у видокругу казивача, али ће се наћи и оне које су удаљене, али су имале важну улогу у догађајима који су били важни за опстанак колектива.

На основу богате грађе можемо закључити да се о манастирима певало и приповедало у свим жанровима: лирским песмама, епско-лирским, епским и предањима. Сакралне грађевине биле су присутне у свакодневном животу: преко литургије, тражења спаса и утехе, савладавања Турака, окајавања грехова, али и веза између Косовске битке и светитељске иницијације. Каталог манастира се разликује од каталога у другим српским срединама, а те разлике су углавном везане за позиционирање оних манастира које су Немањићи градили у Старој Србији и који су у свести Косоваца имали значајно место, пре свега у литургијском животу и очувању идентитета. У овом раду смо

\footnotetext{
${ }^{4}$ „Одатле се диже Петар и оде у Цариград. Продаде стоку, продаде три иљаде волова и три иљаде коња. По то се диже те код патријара да га упита што ће да му рекне патријар, како може он да добије берат од султана за цркву (Бован 4, 1980: 128).
} 
показали како изгледа каталог, а корак даље био би компаративна анализа каталога из других средина, као и преглед преживелих и порушених сакралних грађевина, што би био нов прилог проучавању задужбинарства у Срба.

\section{ИЗВОРИ}

Бован 1980: В. Бован 1, Народна књижевност Срба на Косову, Лирске песме 1, Београд: Јединство.

Бован 1980: В. Бован 2, Народна књижевност Срба на Косову, Лирске песме 2, Приштина: Јединство.

Бован 1980: В. Бован 3, Народна књижевност Срба на Косову, Приповедне песме, Приштина: Јединство.

Бован 1980: В. Бован 4, Народна књижевност Срба на Косову, Народне приповетке 1, Приштина: Јединство.

Бован 1980: В. Бован 5, Народна књижевност Срба на Косову, Јуначке песме, Приштина: Јединство.

Дебељковић 1984: Д. Дебељковић, Српске народне умотворине са Косова и Метохије из рукописа Дене Дебељковића, Приштина: Академија наука и уметности Косова.

Јастребов 1886: И. С. Јастребов. Обичаи и песни турецкиъ Сербовъ, С. Петербург.

Караџић 1969: В. С. Караџић, Српске народне пјесме, Београд: Просвета.

\section{ЛИТЕРАТУРА}

Ајдачић 1996: Д. Ајдачић, „Чудесно дрво у народним песмама балканских Словена", у: Кодови словенских култура, биљке, бр. 1, Clio.

Елијаде 2003: М. Елијаде, Свето и профано, Сремски Карловци, Нови Сад. Задужбине Косова и Метохије, историјско, духовно и културно наслеђе српског народа, Призрен-Београд: Епархија рашко-призренска и косовскометохијска.

Јастребов 2, 2018: И. С. Јастребов, Стара Србија и Албанија, Београд: Службени гласник.

Костић 1980: Д. Костић „Народна песма о зидању Високих Дечана”, у Народна књижевност Срба на Косову, Приштина: Јединство.

Љубинковић 2010: Н. Љубинковић, Трагања и одговори, Београд: Институт за књижевност и уметност.

Милошевић Ђорђевић 1971: Н. Милошевић Ђорђевић, Заједничка тематско-сижејна основа српскохрватских неисторијских епских песама и прозне традищије, Београд.

Николић 1997: О. Николић, „Књижевна култура у храмовима Дренице”, у Баштина, Приштина, VIII/1997/8. 
Нојман 1994: Е. Нојман, Историјско порекло свести, Београд.

Павловић 1993: М. Павловић, Огледи о народној и старој српској поезији, Београд: СКЗ.

Цвијић 1991: Ј. Цвијић, Балканско полуострво, Београд: САНУ.

Чајкановић 1994: В. Чајкановић, Стара српска религија и митологија, Београд: СКЗ, БИГЗ, Просвета, Партенон М.А.М.

Библија 1986: Biblija ili Sveto pismo staroga i novoga zavjeta, Britansko i inozemno biblijsko društvo, Beograd.

Valentina D. Pitulić

\section{THE CATALOGUE OF THE MONASTERIES IN THE ORAL LORE FROM KOSOVO AND METOHIJA}

(Summary)

The focus of this paper is the catalogue of the monasteries in the oral lore from Kosovo and Metohija. The analysis of the available corpus has shown that the monastic endowment motif was prevalent in all the genres of the collective memory. The oral singer focused on those monasteries and churches which were part of his perception and daily life.

In the first part of the paper, the focus is on the mythological level of narration, in which the ancient deity of the Serbs (tree) is substituted with church, which indicates the slow Christianisation of the archaic corpus. It becomes evident that church, in particular in the lyrical ecclesiastical poems, is a sacral edifice which comes from the heavens, which will also be the case in the belief narrative about the building of the monastery of Gračanica. For the oral singer, church was part of daily life, thus it can be encountered, unnamed, in love poems, while the catalogue of monastic endowments will appear in narrative, epic poems and belief narratives.

The analysis of the existing corpus from Kosovo and Metohija, which has not been studied thoroughly enough, provides us with an insight into how important the role of the monastic endowment in identity preservation is, but also how aware the people are of the importance of liturgical life in the area which was endangered by many conquerors throughout the centuries. 